\title{
Starania władz polskich o umiejscowienie na terytorium Rzeczypospolitej stałej bazy wojskowej Sił Zbrojnych Stanów Zjednoczonych
}

Zarys treści: W ostatnich latach nasiliły się starania władz polskich o umiejscowienie na terytorium Rzeczypospolitej stałej bazy wojskowej Sił Zbrojnych Stanów Zjednoczonych. Polska wyszła z bardzo ambitną propozycją umieszczenia na jej obszarze amerykańskiej dywizji pancernej i budowy „Fortu Trump”. Jak dotąd nie została ona wcielona w życie, jednak Stany Zjednoczone stopniowo zwiększają obecność wojskową na terytorium Polski.

Outline of content: In recent years, the efforts of the Polish authorities to locate the permanent military base of the United States Armed Forces in the territory of the Republic of Poland have intensified. Poland came out with a very ambitious proposal to locate the U.S. armoured division and build 'Fort Trump' on its territory. It has not yet been implemented, but the United States is gradually increasing its military presence on Polish territory.

Słowa kluczowe: Polska, Stany Zjednoczone, siły zbrojne, baza wojskowa, NATO

Keywords: Poland, United States, armed forces, military base, NATO

\section{Wprowadzenie}

Zwrócenie się polskich elit politycznych i społeczeństwa do Stanów Zjednoczonych wynikało z czynników zarówno obiektywnych, jak i emocjonalnych. Państwo to wyszło z zimnej wojny jako niekwestionowany zwycięzca i supermocarstwo ze wszystkimi jego atrybutami. W Polsce panowała wiara w Amerykę jako bogaty, lepszy świat, podbudowana legendą o wspólnej walce o niepodległość ${ }^{\text {. Bolesne }}$

${ }^{1}$ J. Kiwerska, Kwestie bezpieczeństwa $w$ stosunkach polsko-amerykańskich. Trendy i perspektywy, w: Bezpieczeństwo Polski. Współczesne wyzwania, red. S. Wojciechowski, A. Potyrała, Warszawa 2014, s. 60 . 
doświadczenia historyczne Polaków ze strony potężnych sąsiadów - głównie Rosji i Niemiec - sprawiały, że szukali oni gwarancji bezpieczeństwa za Atlantykiem². Zaufanie do USA pogłębiło bliższe wsparcie Solidarności przez administrację prezydenta Ronalda Reagana i podkopywanie przez nią radzieckiej kontroli nad Europą Środkowo-Wschodnią ${ }^{3}$. W Stanach Zjednoczonych doceniana była z kolei niezłomna walka Polaków o wolność, niepodległość i suwerenność. Bez strategicznego położenia i znaczących złóż naturalnych Rzeczpospolita znajdowała się jednak poza główną sferą zainteresowań USA ${ }^{4}$.

Już w 1989 r. Kongres USA zatwierdził $300 \mathrm{mln}$ USD na promocję demokracji i liberalizmu ekonomicznego w Polsce i na Węgrzech. W późniejszym okresie do Polski i innych państw regionu kierowane były kolejne formy wsparcia ze strony Waszyngtonu ${ }^{5}$. Co ważniejsze, administracja prezydenta Billa Clintona poparła rozszerzenie NATO o Polskę i inne państwa postkomunistyczne. Stało się tak pomimo sprzeciwu Rosji i niechęci wojskowego establishmentu w samych Stanach Zjednoczonych ${ }^{6}$. Przedstawiona w październiku 1993 r. kompromisowa inicjatywa Partnerstwa dla Pokoju (Partnership for Peace - PdP/PfP) stanowiła drogę do pełnego członkostwa w organizacji ${ }^{7}$. Polskim władzom zależało, aby zdobyć wiarygodność w USA i NATO. Z tego względu zdecydowały one o aktywnym włączeniu Wojska Polskiego do działań pokojowych w Bośni i Hercegowinie oraz innych formach współpracy wojskowej.

Z biegiem lat Polska została najbliższym sojusznikiem Stanów Zjednoczonych w Europie Środkowo-Wschodniej. Kierunki polityki zagranicznej i bezpieczeństwa Polski stały się bliskie interesom USA. Waszyngton zaczął postrzegać rozwijającą się Polskę jako potencjalnego lidera regionu9. Pojawiały się jednak słowa krytyki. Według Davida Sylvana i Stephena Majeskiego tylko Polska, spośród państw postkomunistycznych, stała się klientem Stanów Zjednoczonych. Przemawiać miały za tym formuła kooperacji w obszarze polityczno-wojskowym i specyfika retoryki $\mathrm{w}$ relacjach dwustronnych ${ }^{10}$. Entuzjastyczne poparcie dla działań USA na

2 R.J. Lieber, The United States and Europe: Explaining the Transatlantic Bonds, w: American Foreign Policy in a Globalized World, ed. D.P. Forsythe, P.C. McMahon, A. Wedeman, London-New York 2006, s. 275.

3 C.D. Walton, Grand Strategy and the Presidency. Foreign Policy, War and the American Role in the World, London-New York 2012, s. 167-168.

4 J. Kiwerska, op. cit., s. 61.

${ }^{5}$ N. Bouchet, Democracy Promotion as US Foreign Policy Bill Clinton and Democratic Enlargement, London-New York 2015, s. 38.

${ }^{6}$ A. Toje, America, the EU and Strategic Culture. Renegotiating the Transatlantic Bargains, London-New York 2008, s. 92.

7 J. Dumbrell, Clinton's Foreign Policy Between the Bushes, 1992-2000, London-New York 2009, s. 126.

${ }^{8}$ N. Bouchet, op. cit., s. 88.

9 Ibidem, s. 88.

10 D. Sylvan, S. Majeski, U.S. Foreign Policy in Perspective. Clients, Enemies and Empire, LondonNew York 2009, s. 57, 69. 
arenie międzynarodowej wiązało się z oczekiwaniami ochrony i wdzięczności za lojalność. Gdy jednak Waszyngton popełniał błędy i nie zaspokajał pokładanych $\mathrm{w}$ nim nadziei, $\mathrm{w}$ społeczeństwie polskim stopniowo spadała wiara w mityczną Amerykę ${ }^{11}$. Szczególnie wyraźne było to w okresie prezydentury George’a W. Busha. W mniejszym stopniu rzutowało to na postawę władz polskich, które doceniały nawet symboliczne gesty ze strony USA. Ryszard Zięba postawił zdecydowaną, choć dla części badaczy kontrowersyjną tezę, że między 1999 a 2007 r. prowadzono politykę bandwagoningu, a momentami nawet klientelizmu i samowasalizacji wobec Waszyngtonu ${ }^{12}$.

Szczególny obszar współpracy między Polską i USA stanowiły działania w ramach wielonarodowych operacji wojskowych. Tuż po wejściu do NATO Polska poparła zainicjowaną przez Waszyngton, a dyskusyjną prawnie i politycznie „interwencję humanitarną” w Kosowie ${ }^{13}$. Poparcie Warszawy było bardziej zdeterminowane niż to prezentowane przez wielu tradycyjnych sojuszników USA ${ }^{14}$. Nowy rozdział kooperacji otworzyła wojna z międzynarodowym terroryzmem. W Afganistanie Wojsko Polskie zaangażowało się zarówno w operację antyterrorystyczną pod amerykańskim dowództwem, jak i w działania stabilizacyjne prowadzone przez $\mathrm{NATO}^{15}$. Kiedy na prośbę Waszyngtonu w 2009 r. Polska wydatnie wzmacniała kontyngent $\mathrm{w}$ prowincji Ghazni, decyzję tę popierało zaledwie 17\% społeczeństwa. Nie powstrzymało to jednak władz, twierdzących, że działanie to leżało $\mathrm{w}$ interesie bezpieczeństwa Polski ${ }^{16}$.

Znacznie poważniejsze kontrowersje wzbudziła jednak wojna w Iraku. Brak legitymacji gremiów międzynarodowych oraz sprzeciw światowych i europejskich mocarstw nie wpłynęły na proamerykańską postawę Warszawy ${ }^{17}$. Pozostała ona niezachwiana w sytuacji, gdy administracja amerykańska gotowa była poróżnić europejskich sojuszników, aby móc zrealizować założony cel polityczny. Wdzięczność za przyjęcie do NATO i potrzeba umacniania więzi sojuszniczej z USA motywowały władze polskie do poparcia wojny $\mathrm{w} \mathrm{Iraku}^{18}$. W ramach wąskiej „koalicji

11 A. Balcer, K. Wóycicki, Polska na globalnej szachownicy, Warszawa 2014, s. 317.

12 R. Zięba, Polityka zagraniczna Polski w strefie euroatlantyckiej, Warszawa 2013, s. 118.

${ }^{13}$ H. Gardner, American Global Strategy and the „War on Terrorism”, London-New York 2016, s. 173.

14 N. Bouchet, op. cit., s. 88.

15 R. Grodzki, Polska polityka zagraniczna w XX i XXI wieku. Główne kierunki - Fakty - Ludzie - Wydarzenia, Zakrzewo 2009, s. 262-263.

16 D.G. Haglund, The US-Canada relationship: How 'special' is America's oldest unbroken alliance?, w: America's 'Special Relationships'. Foreign and Domestic Aspects of the Politics of Alliance, ed. J. Dumbrell, A.R. Schäfer, London-New York 2009, s. 71.

17 F. Cameron, US Foreign Policy after the Cold War. Global Hegemon or Reluctant Sheriff? Second edition, London-New York 2005, s. 166.

18 J. Symonides, Polityka zagraniczna Polski a ład międzynarodowy, w: Polityka zagraniczna Polski po wstapieniu do NATO $i$ do Unii Europejskiej. Problemy tożsamości i adaptacji, red. S. Bieleń, Warszawa 2010, s. 94. 
chętnych" Wojsko Polskie uczestniczyło w obaleniu reżimu prezydenta Saddama Husajna ${ }^{19}$. Symboliczna pomoc militarna z okresu interwencji zbrojnej przerodziła się w wydatny wysiłek stabilizacyjny ${ }^{20}$. Przy wsparciu ze strony USA Polska wzięła na siebie odpowiedzialność za dowodzenie wielonarodową dywizją i utrzymanie bezpieczeństwa $\mathrm{w}$ jednej z czterech stref okupacyjnych Iraku ${ }^{21}$. Gdy Warszawa zaczęła się jednak upominać o obiecane korzyści, Waszyngton pozostawał niewzruszony $^{22}$. Mimo braku oczywistych interesów w Iraku władze polskie przekonywały do zasadności uczestnictwa $\mathrm{w}$ misji ${ }^{23}$. Ich wiarę podsycały przemówienia prezydenta Busha o wspólnocie wartości i gotowości ich obrony ramię w ramię przez Amerykanów i Polaków ${ }^{24}$. Pozory „sprawiedliwej wojny” próbowano zachować nawet po ujawnieniu sposobu traktowania "nielegalnych bojowników” w tajnych obozach Centralnej Agencji Wywiadowczej USA (Central Intelligence Agency CIA) w Polsce i Rumunii ${ }^{25}$.

Współpraca polityczno-wojskowa między Polską i Stanami Zjednoczonymi obejmuje również inne obszary, w tym handel bronią. Kolejne programy modernizacji polskiej armii w znacznej mierze realizowane były w oparciu o systemy uzbrojenia pochodzące z USA. Jak dotąd największy wydźwięk miała umowa z kwietnia 2003 r., dotycząca zakupu 48 samolotów wielozadaniowych F-16, nazwana przez komentatorów „kontraktem stulecia” 26 . Wrażenie robią także umowy podpisane w ostatnich latach - odnoszące się do zakupu baterii przeciwlotniczych Patriot, śmigłowców Black Hawk czy mobilnych wyrzutni HIMARS oraz plan zakupu myśliwców F-35 ${ }^{27}$. Transakcje zawierane są przy rozczarowaniu oferentów z państw Europy Zachodniej. Nie można jednak podważyć faktu, że wysoki poziom zaawansowania technologicznego przemysłu zbrojeniowego czyni z USA atrakcyjnego partnera w obszarze współpracy wojskowo-technicznej ${ }^{28}$. Polsko-amerykańskie stosunki polityczno-wojskowe to także setki odbywanych ćwiczeń

19 O.R. Holsti, Making American Foreign Policy, London-New York 2006, s. 347.

${ }^{20}$ L.R. Lee, US Hegemony and International Legitimacy. Norms, Power and Followership in the Wars on Iraq, London-New York 2010, s. 108.

${ }^{21}$ E. Hallams, The United States and NATO since 9/11. The Transatlantic Alliance Renewed, London-New York 2010, s. 94.

${ }^{22}$ R. Zięba, Główne kierunki polityki zagranicznej Polski po zimnej wojnie, Warszawa 2010, s. 155.

23 A. Orzelska, Polityka zagraniczna Polski wobec wybranych kwestii spornych $w$ stosunkach transatlantyckich (1989-2004), Warszawa 2011, s. 73.

24 A. Moens, The Foreign Policy of George W. Bush. Values, Strategy, and Loyalty, London-New York 2016, s. 116.

${ }^{25}$ W. Aslam, The United States and Great Power Responsibility in International Society. Drones, Rendition and Invasion, London-New York 2013, s. 109.

${ }^{26}$ H. Gardner, op. cit., s. 29, 130.

27 P. Ciszak, Amerykańskie bazy w Polsce. Rachunek za nie przekracza 2 mld dol., 13.02.2019, https:// www.money.pl/gospodarka/amerykanskie-bazy-w-polsce-rachunek-za-nie-przekracza-2-mld-dol6349076782581889a.html (dostęp: 18.07.2019).

${ }^{28}$ R. Rusak, Wspótpraca wojskowo-techniczna Polski z USA, w: Polska w międzynarodowej współpracy wojskowej, red. T. Kubaczyk, S. Piotrowski, M. Żyła, Warszawa 2016, s. 321. 
i szkoleń, współdziałanie w ramach mniejszych misji ekspedycyjnych, różne kanały konsultacji i kooperacji oraz wspólna służba oficerów i żołnierzy w wielonarodowych instytucjach i jednostkach wojskowych.

\section{Lokalizacja w Polsce instalacji wojskowych USA}

Po zimnej wojnie Stany Zjednoczone ograniczały liczbę żołnierzy stacjonujących w Europie Zachodniej. Szczególnie dotyczyło to baz w Niemczech i Wielkiej Brytanii, a wyjątek od tej reguły stanowiły Włochy. Bazy w Europie Zachodniej zmieniały także przeznaczenie dla Sił Zbrojnych USA, ewoluując w kierunku centrów logistycznych. Jednocześnie Pentagon zaczął przegrupowywać pewne siły do baz w Europie Środkowo-Wschodniej ${ }^{29}$. Główną barierę w tym procesie stanowiło jednak negatywne stanowisko Rosji, która sprzeciwiła się rozszerzaniu wpływów NATO u jej granic ${ }^{30}$. Wymowne były słowa premiera Wiktora Czernomyrdina, że decyzja o rozszerzeniu NATO to „najgorszy i największy błąd od zakończenia zimnej wojny"31. Jednoznaczny był przekaz prezydenta Władimira Putina, który wielokrotnie ostrzegał, że nie będzie tolerował rozwoju u granic Rosji „machiny wojennej NATO”32. Jednocześnie to właśnie skomplikowane stosunki między Waszyngtonem i Moskwą stanowią powód zwiększania zaangażowania wojskowego Stanów Zjednoczonych w Europie Środkowo-Wschodniej, w której mocarstwa mają sprzeczne interesy. USA niezmiennie zależy na stabilizacji tego regionu i ugruntowaniu w nim wartości demokratycznych w ścisłej współpracy z Zachodem.

Jeszcze na początku drugiej dekady XXI w. stacjonowanie żołnierzy amerykańskich w Polsce wyglądało bardzo skromnie. Jego początki wiążą się z obroną powietrzną. Od kwietnia $2010 \mathrm{r}$. w Morągu rotacyjnie stacjonowała jedna bateria amerykańskiego systemu przeciwlotniczego Patriot, przenoszona wraz z obsługującym ją personelem wojskowym w liczbie ok. 100 osób co kwartał na miesiąc z bazy Kaiserslautern w Niemczech. Początkowo był to system ćwiczebny, a w późniejszym okresie w pełni uzbrojony $^{33}$. Od listopada 2012 r. w Łasku stacjonuje na stałe 10-, a od 2013 r. 20-osobowy pododdział w ramach 52 Operations Group Detachment 1. Do jego zadań należą obsługa amerykańskich samolotów F-16 Fighting Falcon i C-130 Hercules, szkolenie pilotów i organizacja ćwiczeń wojskowych ${ }^{34}$.

29 H. Gardner, op. cit., s. 128.

${ }^{30}$ L.A.M. Bandeira, The Second Cold War. Geopolitics and the Strategic Dimensions of the USA, New York 2017, s. 22.

31 B. Hansen, P. Toft, A. Wivel, Security Strategies and American World Order Lost Power, London-New York 2009, s. 41.

32 L.A.M. Bandeira, op. cit., s. 64.

33 E. Żemła, Rakiety Patriot w Polsce, „Rzeczpospolita” (25 V 2010), http://archiwum.rp.pl/artykul/950270-Rakiety-Patriot-w-Polsce.html (dostęp: 18.07.2019).

${ }^{34}$ NATO-U.S. Military Presence in Poland, https://pl.usembassy.gov/nato_us/ (dostęp: 10.07.2019). 
Na początku 2017 r. do Powidza trafiły pododdziały amerykańskiej Brygady Lotnictwa Bojowego, zapewniające transport medyczny i wsparcie ćwiczeń. W miejscowości tej zlokalizowana została także brygadowa grupa zadaniowa wyposażona w śmigłowce różnego typu oraz jednostki logistyczne ${ }^{35}$. W maju $2018 \mathrm{r}$. w Mirosławcu pojawiła się 52 Operations Group Detachment 2 wyposażona w bezzałogowe statki powietrzne MQ-9 Reaper. Te zaawansowane technologicznie drony mogą przenosić ok. 1,4 tony uzbrojenia, w tym kierowane laserowo bomby i pociski przeciwpancerne ${ }^{36}$.

Znaczący wzrost zaangażowania Sił Zbrojnych USA w Polsce jest efektem odpowiedzi NATO na kryzys na Ukrainie z przełomu 2013 i 2014 r. W czerwcu 2014 r. Waszyngton wystąpił z Europejską Inicjatywą Wsparcia (European Reassurance Initiative - ERI). Mimo że kryzys pojawił się w okresie strategicznego zwrotu Waszyngtonu ku regionowi Azji i Pacyfiku oraz redukcji wydatków na zbrojenia, to administracja prezydenta Baracka Obamy wywiązała się z sojuszniczych zobowiązań wobec Polski i innych państw Europy Środkowo-Wschodniej ${ }^{37}$. W ramach współpracy dwustronnej od stycznia 2017 r. w Polsce stacjonuje amerykańska Pancerna Brygadowa Grupa Bojowa. Jej dowództwo mieści się w Żaganiu, natomiast podległe bataliony rozmieszczone są także w Bolesławcu, Skwierzynie i Świętoszowie. W skład poszczególnych zmian wchodzi ok. 3,5 tys. żołnierzy i prawie 2 tys. pojazdów, w tym czołgi M1 Abrams, bojowe wozy piechoty M2 Bradley, samobieżne haubice Paladin i samochody Humvee ${ }^{38}$. W kwietniu 2017 r. w ramach wzmocnionej Wysuniętej Obecności NATO (enhanced Forward Presence - eFP) do Orzysza przegrupowana została batalionowa grupa bojowa, w której państwem ramowym są Stany Zjednoczone. Do poszczególnych rotacji grupy Siły Zbrojne USA delegują między 800 a 900 żołnierzy, głównie szwadronu kawalerii pancernej, wyposażonych m.in. w kołowe wozy opancerzone Stryker, baterię haubic M777A2 i samochody terenowe Humvee ${ }^{39}$. Na początku maja 2017 r. z Baumholder w Niemczech do Poznania przeniesione zostało Centrum Dowodzenia Dywizji (Mission Command Element - MCE). Dowództwo to odpowiada za działania

35 Siły NATO. Zobacz, gdzie i jakie jednostki stacjonuja w Polsce, 11.03.2019, https://polskieradio24.pl/5/1222/Artykul/2275925,Sily-NATO-Zobacz-gdzie-i-jakie-jednostki-stacjonuja-w-Polsce (dostęp: 18.07.2019).

36 PAP/AH, Amerykańskie MQ-9 Reaper w Polsce, 4.06.2018, https://www.wnp.pl/przemysl-obronny/ amerykanskie-mq-9-reaper-w-polsce,324468_1_0_0.html (dostęp: 18.07.2019).

37 S. Koziej, M. Fryc, NATO po zakończeniu operacji w Afganistanie, w: Polityczno-wojskowe implikacje członkostwa Polski w NATO z perspektywy 15-lecia obecności w strukturach Sojuszu, red. T. Kośmider, Warszawa 2014, s. 51.

38 R. Lesiecki, Sprzęt brygady pancernej USA wkrótce w Europie. Rozładunek m.in. w Gdań$s k u, 11.09 .2017$, https://www.defence24.pl/sprzet-brygady-pancernej-usa-wkrotce-w-europierozladunek-min-w-gdansku (dostęp: 18.07.2019).

39 M. Zieliński, Jakim uzbrojeniem dysponuje Batalionowa Grupa Bojowa?, „Polska Zbrojna” (25 IV 2017), http://www.polska-zbrojna.pl/home/articleshow/22423?t=Jakim-uzbrojeniem-dysponujeBatalionowa-Grupa-Bojowa-\# (dostęp: 18.07.2019). 
wojsk amerykańskich na wschodniej flance $\mathrm{NATO}^{40}$. Powyższe jednostki nie tylko służą odstraszaniu konwencjonalnemu i zwiększają potencjał bojowy Polski, ale także biorą aktywny udział w szeregu realizowanych w Polsce ćwiczeń sojuszniczych. Warto nadmienić, że amerykańscy oficerowie i żołnierze służą także w instytucjach i jednostkach NATO zlokalizowanych w Szczecinie, Bydgoszczy, Krakowie i Elblągu.

Kontrowersje wzbudziła wystosowana w 2007 r. przez Stany Zjednoczone do Polski, a także Czech propozycja umiejscowienia na ich terytoriach elementów amerykańskiego systemu przeciwrakietowego. Spotkała się ona z dużą przychylnością ze strony rządu polskiego, przy zróżnicowanej postawie polskiego społeczeństwa i komentatorów. Wśród argumentów za rozmieszczeniem elementów tarczy w Polsce znajdowały się przede wszystkim wzmocnienie krajowego systemu obrony powietrznej, zacieśnienie sojuszu i dodatkowe gwarancje bezpieczeństwa ze strony USA, czynnik odstraszania Rosji, tradycyjna odpowiedzialność USA za obronę sojuszników, szansa na pogłębienie współpracy wojskowo-technicznej z USA, szansa na zwiększenie wkładu USA w modernizację polskiej armii. Przeciwnicy tej koncepcji zazwyczaj podnosili następujące argumenty: ryzyko ataku, w tym nuklearnego, na instalację przez państwo trzecie, ryzyko ataku terrorystycznego na instalację, specyfika systemu skoncentrowana na obronie terytorium USA, dalsze uzależnianie Polski od Stanów Zjednoczonych ${ }^{41}$.

Propozycja lokalizacji w Polsce elementów amerykańskiego systemu przeciwrakietowego wzbudziła duże emocje na forum międzynarodowym. Poważnie skomplikowała ona stosunki na linii Waszyngton-Moskwa. Władze rosyjskie porównały to nawet $\mathrm{z}$ kubańskim kryzysem rakietowym z października $1962 \mathrm{r}^{42} \mathrm{~W}$ odpowiedzi Moskwa zawiesiła przestrzeganie szeregu traktatów międzynarodowych dotyczących kontroli i redukcji zbrojeń ${ }^{43}$. Jednocześnie zagroziła rozmieszczeniem pocisków rakietowych w Kaliningradzie i na Białorusi oraz skierowaniem ich w stronę instalacji w Polsce ${ }^{44}$. Obawy przed zaburzeniem równowagi strategicznej przedstawiła również Chińska Republika Ludowa dysponująca dość pokaźnym arsenałem rakietowym i jądrowym ${ }^{45}$. Negatywne głosy pojawiły się nawet wśród sojuszników

40 Ł. Zalesiński, Amerykańskie dowództwo w Poznaniu, „Polska Zbrojna” (8 V 2017), http://www. polska-zbrojna.pl/home/articleshow/22555?t=Amerykanskie-dowodztwo-w-Poznaniu\# (dostęp: 18.07.2019).

${ }^{41}$ F. Shor, Dying Empire. U.S. Imperialism and Global Resistance, London-New York 2010, s. 71 .

${ }^{42}$ B. van Apeldoorn, N. de Graaff, American Grand Strategy and Corporate Elite Networks. The Open Door since the End of the Cold War, London-New York 2016, s. 180.

43 B. Hansen, P. Toft, A. Wivel, op. cit., s. 45.

${ }^{44}$ T. Terriff, Grace, murder, or suicide? The passing of American primacy, w: Debating a Post-American World. What Lies Ahead?, ed. S. Clark, S. Hoque, London-New York 2012, s. 51.

45 R. Steff, Strategic Thinking, Deterrence and the US Ballistic Missile Defense Project. From Truman to Obama, London-New York 2016, s. 102. 
z NATO. Przykładowo Berlin skrytykował Waszyngton za brak pełnej konsultacji w sprawie tarczy z Moskwą ${ }^{46}$.

W zamian za zgodę na umiejscowienie w Polsce elementów tarczy antyrakietowej Warszawa wystąpiła do Waszyngtonu z kilkoma postulatami. Przede wszystkim oczekiwała dodatkowych gwarancji bezpieczeństwa, rozmieszczenia na terytorium Polski systemów Patriot i wsparcia finansowego w modernizacji polskiej armii ${ }^{47}$. $\mathrm{W}$ trakcie negocjacji strona polska popełniła szereg uchybień i momentami można było nawet odnieść wrażenie, że to Warszawa zabiega w Waszyngtonie o realizację tego projektu. Mimo to 20 sierpnia 2008 r. podpisane zostały umowa w sprawie budowy elementu amerykańskiej tarczy w Polsce i towarzysząca jej deklaracja o współpracy strategicznej między państwami. „Reset” w stosunkach amerykańsko-rosyjskich zainicjowany w 2009 r. przez administrację prezydenta Obamy wzbudził jednak duży niepokój w Polsce o przyszłość instalacji i szerzej relacji polsko-amerykańskich ${ }^{48}$. Obawiano się, że przepadną zainwestowany w tę koncepcję kapitał polityczny i wiarygodność sojusznicza USA jako gwaranta bezpieczeństwa Polski ${ }^{49}$. Napięcie pogłębiały redukcja wydatków na zbrojenia w Stanach Zjednoczonych i przyspieszenie rokowań na temat zakończenia programu jądrowego przez Iran, co mogło uczynić projekt bezprzedmiotowym ${ }^{50}$. Ostatecznie Polsce przedstawiony został zmodyfikowany projekt w ramach NATO, który okazał się dla niej bardziej korzystny. Jako priorytet traktuje on bowiem ochronę europejskich sojuszników i zlokalizowanych na ich terytoriach amerykańskich instalacji wojskowych ${ }^{51}$.

\section{Negocjacje w sprawie umiejscowienia w Polsce stałej bazy wojskowej USA}

Władze polskie proponowały stałą obecność żołnierzy amerykańskich na terytorium Rzeczypospolitej już w okresie prezydentury Busha. Inicjatywa ta cieszyła i nadal cieszy się poparciem wszystkich liczących się ugrupowań politycznych w kraju ${ }^{52}$.

${ }^{46}$ D.H. Dunn, B. Zala, Transatlantic relations and US foreign policy, w: Obama and the World New Directions in US Foreign Policy. Second edition, ed. I. Parmar, L.B. Miller, M. Ledwidge, London-New York 2014, s. 208.

47 R. Steff, op. cit., s. 121.

${ }^{48}$ M. David, US-Russia relations in Obama's second term: a damage limitation exercise, w: The Obama Doctrine. A Legacy of Continuity in US Foreign Policy?, ed. M. Bentley, J. Holland, London-New York 2017, s. 166.

49 S.A. Renshon, National Security in the Obama Administration. Reassessing the Bush Doctrine, London-New York 2010, s. 8.

50 A. Warren, The Obama Administration's Nuclear Weapon Strategy. The Promises of Prague, London-New York 2014, s. 26.

${ }^{51}$ R. Steff, op. cit., s. 110.

${ }^{52}$ K. Kamiński, Stała Baza Wojskowa USA w Polsce, „Dziennik Związkowy” (25 II 2019), http://dziennikzwiazkowy.com/warsaw-institute/stala-baza-wojskowa-usa-w-polsce/ (dostęp: 18.07.2019). 
W lutym 2003 r. przewodniczący Komisji Sił Zbrojnych w Izbie Reprezentantów USA - republikański kongresmen Duncan L. Hunter opowiadał się za przesunięciem baz wojskowych USA z Niemiec do państw postkomunistycznych ${ }^{53}$. Wzmożona debata na ten temat prowadzona była jednak w burzliwych okolicznościach przygotowywania się do wojny w Iraku, przeciwko której Berlin zdecydowanie protestował. W wyniku zapoczątkowanej jeszcze przez prezydenta Busha próby poprawy stosunków między USA a Niemcami pomysł ten został odłożony na wiele lat. Na początku 2018 r. w Polsce stacjonowało ok. 4,3 tys. amerykańskich żołnierzy, głównie na zasadzie stałej rotacji. Stanowiło to największy kontyngent USA na wschodniej flance NATO i czwarty w Europie po Niemczech (37,5 tys.), Włoszech (12 tys.) i Wielkiej Brytanii (8,3 tys. $)^{54}$.

W maju 2018 r. do opinii publicznej wyciekła opracowana w Ministerstwie Obrony Narodowej „Propozycja stałej obecności USA w Polsce”. Autorzy dokumentu zabiegali o stworzenie na terytorium Polski stałej bazy dla amerykańskiej dywizji pancernej. Zadeklarowano w nim możliwość partycypacji w kosztach budowy i utrzymania bazy na poziomie od 1,5 do 2 mld USD. Propozycja ta miała przekonać Kongres USA do zatwierdzenia koncepcji w trudnej sytuacji budżetowej. Jako miejsce lokalizacji bazy zaproponowano region bydgosko-toruński, który, według autorów dokumentu, miał spełniać wszystkie wymagania w zakresie infrastruktury, zakwaterowania i możliwości szkolenia wojsk ${ }^{55}$. Projekt miał zostać przesłany stronie amerykańskiej bez konsultacji z prezydentem Polski, który jest najwyższym zwierzchnikiem Sił Zbrojnych RP, i Ministerstwem Spraw Zagranicznych ${ }^{56}$.

W maju 2018 r. obie izby Kongresu odniosły się do propozycji lokalizacji stałej bazy wojskowej w Polsce. Izba Reprezentantów wezwała do wzmocnionej stałej obecności USA w Europie, m.in. poprzez rozmieszczenie brygady lotnictwa bojowego Wojsk Lądowych wraz z jednostkami wsparcia. Senat z kolei zobowiązał sekretarza obrony do zbadania możliwości rozmieszczenia w Polsce brygady pancernej ${ }^{57}$. Wśród amerykańskich ekspertów pojawiły się poważne wątpliwości co do zasadności rozmieszczenia w Polsce zgrupowania wojsk w sile dywizji, czyli

53 USA. Komisja Huntera o przenosinach niemieckich baz m.in. do Polski, „Gazeta Wyborcza” (27 II 2003), http://wyborcza.pl/1,75248,1349113.html?disableRedirects=true (dostęp: 18.07.2019).

${ }^{54}$ J. Bielecki, Polska bazq USA na flance wschodniej, „Rzeczpospolita” (11 I 2019), https://www. rp.pl/Polityka/301109904-Polska-baza-USA-na-flance-wschodniej.html (dostęp: 18.07.2019).

55 Ministry of National Defence Republic of Poland, Proposal for a U.S. Permanent Presence in Poland, s. 2, https://g8fip1kplyr33r3krz5b97d1-wpengine.netdna-ssl.com/wp-content/uploads/2018/05/ Proposal-for-a-U.S.-Permanent-Presence-in-Poland-2018.pdf (dostęp: 10.07.2019).

${ }^{56}$ E. Żemła, K. Turecki, Poland offers US up to $\$ 2 B$ for permanent military base, „Politico” (27 V 2018), https://www.politico.eu/article/nato-poland-offers-us-up-to-2-billion-for-permanentamerican-military-base/ (dostęp: 18.07.2019).

57 J. Graf, J. Palowski, Stała obecność wojsk USA zmieni status bezpieczeństwa Polski [ANALIZA], 5.06.2018, https://www.defence24.pl/stala-obecnosc-usa-zmieni-status-bezpieczenstwa-polskianaliza (dostęp: 18.07.2019). 
do 15 tys. żołnierzy. Ponadto sekretarz armii w Departamencie Obrony USA Mark Esper stwierdził, że proponowany obszar stacjonowania jest zbyt mały na potrzeby ćwiczenia artylerii. Wskazał też ewentualną konieczność modernizacji wysłużonej infrastruktury drogowej, która utrudnia transport ciężkiego sprzętu wojskowego ${ }^{58}$.

29 czerwca 2018 r. w „The Washington Post” ukazał się głośny artykuł na temat planów dotyczących przegrupowania amerykańskich sił stacjonujących w Europie. Miały one zakładać wycofanie znacznej liczby żołnierzy z Niemiec do USA oraz skierowanie niektórych jednostek do Polski. Wśród powodów drugiej propozycji wskazano prowadzenie przez Warszawę znacznie bliższej Waszyngtonowi polityki bezpieczeństwa, niż przez Berlin. Akcentowano wydatkowanie przez Polskę 2\% PKB na obronność i gotowość partycypacji w kosztach funkcjonowania bazy ${ }^{59}$.

18 września 2018 r. podczas spotkania w Waszyngtonie prezydentów Andrzeja Dudy i Donalda Trumpa podpisana została deklaracja o partnerstwie strategicznym. Dotyczyła ona głównie pogłębienia współpracy w zakresie bezpieczeństwa i obronności ${ }^{60}$. Rozmawiano również na temat możliwości zwiększenia liczby amerykańskich żołnierzy i sprzętu wojskowego w Polsce. Prezydent Duda zaproponował budowę stałej bazy wojskowej USA i nazwanie jej „Fortem Trump”. Prezydent Trump powiedział, że Polska zadeklarowała poczynienie „ogromnego wkładu”, aby umiejscowić stałą bazę USA na swoim terytorium, co uznał za „piękny przykład" dla innych. Stwierdził, że bezpieczeństwo Polski jest bardzo ważne dla niego osobiście i dla USA oraz że administracja amerykańska poważnie rozważy tę możliwość ${ }^{1}$. Prezydent Duda stwierdził z kolei, że w obliczu destabilizacyjnych działań Rosji w Europie Środkowo-Wschodniej stałe stacjonowanie wojsk USA byłoby najlepszą gwarancją bezpieczeństwa ${ }^{62}$.

W grudniu 2018 r. waszyngtońska organizacja non profit - Atlantic Council wydała raport, w którym zaleciła zwiększenie obecności wojskowej USA w Europie

58 R. Korzycki, Amerykańska baza wojskowa w Polsce. Fort Trump wcale nie taki pewny, „Gazeta Prawna" (4 III 2019), https://www.gazetaprawna.pl/artykuly/1400955,amerykanska-baza-wojskowa-w-polsce.html (dostęp: 18.07.2019).

59 J. Hudson, P. Sonne, K. DeYoung, J. Dawsey, U.S. assessing cost of keeping troops in Germany as Trump battles with Europe, "The Washington Post” (29 VI 2018), https://www.washingtonpost.com/world/national-security/us-assessing-cost-of-keeping-troops-in-germany-as-trumpbattles-with-europe/2018/06/29/94689094-ca9f-490c-b3be-b135970de3fc_story.html (dostęp: 18.07.2019).

60 Donald Trump i Andrzej Duda podpisali wspólna deklarację o partnerstwie strategicznym, „Rzeczpospolita" (18 IX 2018), https://www.rp.pl/Dyplomacja/180919339-Donald-Trump-i-Andrzej-Dud a-podpisali-wspolna-deklaracje-o-partnerstwie-strategicznym.html (dostęp: 18.07.2019).

61 The White House, Remarks by President Trump and President Duda of the Republic of Poland Before Bilateral Meeting, 18.09.2018, https://www.whitehouse.gov/briefings-statements/ remarks-president-trump-president-duda-republic-poland-bilateral-meeting/ (dostęp: 18.07.2019).

62 The White House, Remarks by President Trump and President Duda of the Republic of Poland in Joint Press Conference, 18.09.2018, https://www.whitehouse.gov/briefings-statements/ remarks-president-trump-president-duda-republic-poland-joint-press-conference/ (dostęp: 18.07.2019). 
Środkowo-Wschodniej ${ }^{63}$. Tego samego miesiąca szef Gabinetu Prezydenta RP Krzysztof Szczerski spotkał się doradcą ds. bezpieczeństwa narodowego Johnem Boltonem. Po spotkaniu powiedział on, że amerykański prezydent jest przekonany o potrzebie zwiększenia kontyngentu wojskowego w Polsce, a jego koncepcja wydaje się jeszcze bardziej ambitna niż „Fort Trump”. Wzmocnienie obecności w Polsce zapewniłoby bezpieczeństwo całemu regionowi, od Estonii po Bułgarię. Polska, jako bliski sojusznik USA, miała stać się jej regionalną bazą bezpieczeństwa. $\mathrm{Z}$ tego względu Amerykanie planowali rozwój istniejących miejsc stacjonowania sił, jak i tworzenie nowych ${ }^{64}$.

12 lutego 2019 r. ambasador USA przy NATO Kay B. Hutchison stwierdziła, że ustanowienie $\mathrm{w}$ Polsce nowej bazy amerykańskiej niekoniecznie musi oznaczać zmniejszenie obecności wojskowej w Niemczech. Była to próba uspokojenia rządu Niemiec w ramach debaty, jaką wywołał artykuł "The Washington Post” z czerwca 2018 r. ${ }^{65} \mathrm{~W}$ tym samym miesiącu pojawiły się informacje o amerykańskich symulacjach dotyczących rozmieszczenia na stałe w Poznaniu dużego sztabu pod dowództwem dwu- lub nawet trzygwiazdkowego generała. W jego gestii mialaby być koordynacja działań armii USA na wschodniej flance NATO. Do Łasku i Mirosławca rozważano przegrupowanie jednostek lotniczych, do Krakowa - wojsk specjalnych, a do Powidza - dodatkowego sprzętu wojskowego ${ }^{66}$.

1 marca 2019 r. Pentagon przekazał Kongresowi raport dotyczący zasadności i wykonalności koncepcji zwiększenia wojskowej obecności na terytorium Polski ${ }^{67}$. Kilka dni później prezydent Trump powiedział, że sojusznicy, na których terytorium stacjonują amerykańscy żołnierze, powinni w pełni pokrywać koszt ich utrzymania i dodatkowo płacić 50\% lub więcej za przywilej ich goszczenia. $Z$ racji liczby żołnierzy największe koszty przypadłyby Japonii, Niemcom i Korei Południowej, czyli bogatym państwom, na których bezpieczeństwo amerykański podatnik nie chce więcej łożyć. Obecnie państwa ponoszą różny poziom kosztów utrzymania baz amerykańskich - między 20 a nawet $75 \%{ }^{68}$. Postawa prezydenta Trumpa została

${ }^{63}$ P. Breedlove, A. Vershbow, Permanent Deterrence: Enhancements to the US Military Presence in North Central Europe, 12.2018, https://www.atlanticcouncil.org/images/publications/Permanent-Deterrence-Enhancements-to-the-US-Military-Presence-in-North-Central-Europe.pdf (dostęp: 10.07.2019).

${ }^{64} \mathrm{~J}$. Bielecki, op. cit.

${ }^{65} \mathrm{~K}$. Rempfer, A new base in Poland wouldn't take US troops from Germany, US ambassador says, „Military Times” (12 II 2019), https://www.militarytimes.com/news/your-army/2019/02/12/a-newbase-in-poland-wouldnt-take-us-troops-from-germany-us-ambassador-says/ (dostęp: 18.07.2019).

${ }^{66}$ Amerykanie rozważaja stała obecność m.in. w Poznaniu, Krakowie, Łasku i Mirosławcu, 25.02.2019, https://www.defence24.pl/amerykanie-rozwazaja-stala-obecnosc-min-w-poznaniu-krakowie-laskui-miroslawcu (dostęp: 18.07.2019).

67 W.J. Hennigan, Fort Trump? The Pentagon Takes a Step Toward Establishing Base in Poland, „Time” (14 III 2019), https://time.com/5551061/poland-military-base-fort-trump/ (dostęp: 18.07.2019).

68 PAP, „Rz”: Nie przepłacimy za Fort Trump. Jest porozumienie Polski i USA w sprawie budowy bazy, 10.06.2019, https://businessinsider.com.pl/polityka/fort-trump-ile-kosztuja-bazy-wojsk-usaw-polsce/el8g4yy (dostęp: 18.07.2019). 
skrytykowana przez wiele środowisk, w tym głównie demokratów. Zarzucili oni prezydentowi, że nie rozumie, że stacjonowanie to leży także $\mathrm{w}$ interesie USA ${ }^{69}$.

W celu dopracowania kwestii zwiększenia wojskowej obecności USA w Polsce w połowie marca 2019 r. do Warszawy przybył specjalny wysłannik Pentagonu podsekretarz obrony ds. polityki John Rood. Grupa robocza ekspertów z Polski i USA po przewodnictwem Rooda i ministra obrony narodowej Mariusza Błaszczaka opracowywała szczegóły koncepcji ${ }^{70}$. W tym czasie główny zastępca sekretarza obrony ds. bezpieczeństwa międzynarodowego Kathryn L. Wheelbarger poinformowała, że negocjacje mogą potrwać jeszcze od pół roku do roku, a kolejne dwa lub trzy lata będzie trzeba poczekać na wdrożenie projektu ${ }^{71}$. Amerykańska gazeta wojskowa „Stars and Stripes” zasugerowała, że ostateczna koncepcja może być bardziej minimalistyczna niż propozycja Polski ${ }^{72}$. Dowódca wojsk amerykańskich w Europie gen. Curtis M. Scaparrotti stwierdzil, że obecność wojsk amerykańskich w Polsce mogłaby polegać na połączeniu stacjonowania wojsk stałych i rotacyjnych ${ }^{73}$. 14 marca 2019 r. szef Biura Bezpieczeństwa Narodowego Paweł Soloch dał do zrozumienia, że w najbliższym czasie nie nastąpi realizacja koncepcji „Fortu Trump”. Powiedział jednak, że w ciągu roku zostanie zwiększona obecność wojsk amerykańskich w Polsce, a formuła ich stacjonowania jest negocjowana ${ }^{74}$. Sytuację tą zdawały się potwierdzać fakty, w tym zmniejszenie po raz pierwszy wydatków USA na ERI ${ }^{75}$.

12 czerwca 2019 r. w Waszyngtonie odbyło się kolejne spotkanie prezydentów Trumpa i Dudy. W kwestii lokalizacji w Polsce stałej bazy Trump prezentował postawę biznesową i wypowiadał się wstrzemięźliwie. Stwierdził, że nie zapadła decyzja $w$ tej sprawie, jednak gdyby taka instalacja miała w Polsce powstać, to byłaby ona „światowej klasy”. Jednocześnie Trump odrzucił możliwość przegrupowania

${ }^{69}$ N. Wadhams, J. Jacobs, President Trump Reportedly Wants Allies to Pay Full Cost of Hosting U.S. Troops Abroad 'Plus 50\%', „Time” (8 III 2019), https://time.com/5548013/trump-allies-paycost-plus-50-troops/ (dostęp: 18.07.2019).

70 Baza USA w Polsce coraz bliżej. Rozmowy w MON, 14.03.2019, https://www.defence24.pl/baza-usa-w-polsce-coraz-blizej-rozmowy-w-mon (dostęp: 18.07.2019).

${ }^{71}$ J. Pappalardo, It Looks Like A U.S. Air Base Is Coming To Poland, 13.03.2019, https://www. popularmechanics.com/military/aviation/a26814044/poland-us-air-base/ (dostęp: 18.07.2019).

72 J. Vandiver, Planning for a US base in Poland gains momentum, „Stars and Stripes” (13 III 2019), https://www.stripes.com/news/planning-for-a-us-base-in-poland-gains-momentum-1.572452 (dostęp: 18.07.2019).

${ }^{73}$ K. Rempfer, Prepare to man Fort Trump? US has made Poland a 'very serious robust offer' for base, „Military Times” (13 III 2019), https://www.militarytimes.com/news/your-military/2019/03/13/ prepare-to-man-fort-trump-us-has-made-poland-a-very-serious-robust-offer-for-base/ (dostęp: 18.07.2019).

74 Stała baza wojsk USA w Polsce? Prezydencki doradca nie pozostawia złudzeń, „Newsweek” (14 III 2019), https://www.newsweek.pl/wideo/stala-baza-wojsk-usa-w-polsce-prezydencki-doradca-niepozostawia-zludzen/vylsveb (dostęp: 18.07.2019).

75 B.T. Wieliński, P. Wroński, Amerykanie nie zbuduja stałej bazy wojskowej w Polsce, 14.03.2019, https://www.euractiv.pl/section/polityka-zagraniczna/news/amerykanie-nie-zbuduja-stalej-bazywojskowej-w-polsce/ (dostęp: 18.07.2019). 
dodatkowych wojsk do Europy, a wzmocnienie kontyngentu w Polsce miało polegać na przeniesieniu amerykańskich żołnierzy $\mathrm{z}$ baz w Europie Zachodniej ${ }^{76}$. W trakcie spotkania prezydenci podpisali deklarację o współpracy wojskowej. Strona amerykańska zobowiązała się do wzmocnienia kontyngentu stacjonującego w Polsce o tysiąc żołnierzy, a Polska do „zapewnienia i utrzymywania wspólnie uzgodnionej infrastruktury przeznaczonej dla wstępnego pakietu dodatkowych projektów", w tym ${ }^{77}$ : Wysuniętego Dowództwa Dywizyjnego USA w Poznaniu, Centrum Szkolenia Bojowego w Drawsku Pomorskim, eskadry bezzałogowych statków powietrznych MQ-9 Sił Powietrznych USA w Łasku, bazy lotniczej załadunkowo-rozładunkowej w celu wspierania przemieszczenia się wojsk USA, grupy wsparcia na teatrze w celu zabezpieczenia obecnych i przyszłych Sił Zbrojnych USA w Polsce, zdolności sił specjalnych USA w celu wsparcia operacji powietrznych, lądowych i morskich, infrastruktury wspierającej obecność w Polsce pancernej brygadowej grupy bojowej, lotniczej brygady bojowej oraz batalionu wsparcia logistycznego.

Po spotkaniu prezydentów minister Błaszczak podkreślił, że zmieniła się formuła stacjonowania amerykańskich żołnierzy w Polsce na „trwałą obecność”. Za jeden z największych sukcesów negocjacyjnych uznał lokalizację w Polsce dowództwa dywizji, któremu mają podlegać wojska amerykańskie stacjonujące na całej wschodniej flance $\mathrm{NATO}^{78}$. Finansowa strona porozumienia winna polegać na jednorazowym wydatkowaniu przez Polskę 2 mld USD na modernizację infrastruktury wojskowej przeznaczonej pod stacjonowanie sił amerykańskich. W późniejszym okresie Polska ma jedynie pokrywać koszty mediów, co może wynosić kilkadziesiąt milionów złotych rocznie ${ }^{79} .23$ września 2019 r. w Nowym Jorku prezydenci Trump i Duda podpisali deklarację o pogłębianiu współpracy obronnej, w której potwierdzili lokalizacje dla większości projektów zadeklarowanych w czerwcu tego samego roku.

\section{Uwarunkowania lokalizacji stałej bazy wojskowej USA w Polsce}

Aktywność wojskowa Rosji na Ukrainie i jej konsekwencje pokazały, że nie można wykluczyć wojny wysokiej intensywności w Europie Środkowo-Wschodniej. Mimo

\footnotetext{
76 The White House, Remarks by President Trump and President Duda of the Republic of Poland Before Bilateral Meeting, 12.06.2019, https://www.whitehouse.gov/briefings-statements/remarks-president-trump-president-duda-republic-poland-bilateral-meeting-2/ (dostęp: 18.07.2019).

77 Wspólna Deklaracja Prezydentów o Wspótpracy Obronnej w zakresie obecności sił zbrojnych USA na terytorium $R P, 16.06 .2019$, https://www.prezydent.pl/aktualnosci/wydarzenia/art,1440,wspolnadeklaracja-prezydentow-o-wspolpracy-obronnej-w-zakresie-obecnosci-sil-zbrojnych-usa-naterytorium-rp.html (dostęp: 18.07.2019).

${ }^{78}$ Gdzie będa stacjonować żołnierze USA w Polsce? Minister Błaszczak: Będzie sześć takich punktów, „Niezależna” (17 VI 2019), https://niezalezna.pl/276080-gdzie-beda-stacjonowac-zolnierze-usaw-polsce-minister-blaszczak-bedzie-szesc-takich-punktow (dostęp: 18.07.2019).

79 PAP, op. cit.
} 
członkostwa w NATO Polska nadal odczuwa zagrożenie ze strony potężnego sąsiada. Z tego względu zabiega o znaczną i stałą obecność wojsk sojuszniczych, głównie amerykańskich, na swoim terytorium ${ }^{80}$. W okresie rozszerzania NATO przywódcy Zachodu zapewniali Rosję, że na obszarze nowych państw członkowskich nie będzie stałej obecności większych zgrupowań sił sojuszniczych. Przyrzeczenie to miało jednak obowiązywać do czasu ewentualnej poważnej zmiany okoliczności bezpieczeństwa ${ }^{81}$. Według Waszyngtonu taka zmiana nastąpiła wraz z rosyjską agresją na Ukrainę, która potępiona została w Strategiach Bezpieczeństwa Narodowego USA z lutego 2015 r. i grudnia 2017 r. Zagroziła ona bowiem normom, „które po zakończeniu zimnej wojny uznawane były za oczywiste"82. Lokalizację w Polsce stałej bazy wojskowej USA wspierają państwa wschodniej flanki NATO, w tym Litwa, Łotwa, Estonia i Rumunia, a także partnerzy Polski z Grupy Wyszehradzkiej - Czechy, Słowacja i Węgry oraz aspirująca do członkostwa w sojuszu Ukraina ${ }^{83}$. Według nich zasadne jest, aby Europy Środkowo-Wschodniej bronili bezpośrednio żołnierze NATO stacjonujący w tym regionie ${ }^{84}$.

Władze suwerennej Polski, niezależnie od ich rodowodu partyjnego, postrzegają Stany Zjednoczone jako kluczowego sojusznika i głównego zewnętrznego gwaranta bezpieczeństwa. W związku z tym Warszawie zależy na nawiązaniu możliwie najbliższych stosunków z Waszyngtonem. W okresie rządów Prawa i Sprawiedliwości sprawa ta ma charakter priorytetowy w stosunku do relacji z państwami tzw. starej Europy. W ostatnich latach polityka zagraniczna i bezpieczeństwa Polski była znacznie bliższa USA niż dominującemu w Unii Europejskiej tandemowi niemiecko-francuskiemu ${ }^{85}$. Postawa taka m.in. miała dać Polsce dobrą pozycję w negocjacjach na temat stałego stacjonowania wojsk amerykańskich na jej terytorium.

W okresie prezydentury Trumpa stosunki między Stanami Zjednoczonymi a wieloma państwami Europy Zachodniej są skomplikowane. Niestandardowe zachowanie amerykańskiego prezydenta i polityka zagraniczna $\mathrm{z}$ myślą przewodnią „Ameryka na pierwszym miejscu” („America First”) krytykują zachodnioeuropejskie elity polityczne. W lipcu $2018 \mathrm{r}$. w siedzibie NATO w Brukseli prezydent Trump podważał znaczenie Sojuszu Północnoatlantyckiego dla USA ${ }^{86}$.

${ }^{80}$ Gaming Out 'Fort Trump' and Other U.S. Military Base Options in Poland, 12.06.2019, https:// worldview.stratfor.com/article/fort-trump-united-states-military-base-options-poland-russiabelarus-map (dostęp: 18.07.2019).

81 D.S. Cloud, U.S. will send more troops to Poland in a move likely to anger Russia, „Los Angeles Times" (12 VI 2019), https://www.latimes.com/politics/la-na-pol-trump-troops-poland-20190612-story.html (dostęp: 18.07.2019).

82 The White House, National Security Strategy, Washington (D.C.) 2015, s. 10, http://nssarchive. us/wp-content/uploads/2015/02/2015.pdf (dostęp: 10.07.2019).

${ }^{83}$ Amerykanie rozważaja stała obecność...

${ }^{84}$ H. Gardner, op. cit., s. 128.

85 Stratfor Worldview, A U.S. Base in Poland Would Drive Russia Nuts, 8.06.2019, https://nationalinterest.org/blog/buzz/us-base-poland-would-drive-russia-nuts-61702 (dostęp: 18.07.2019).

${ }^{86}$ W.J. Hennigan, op. cit. 
Już wcześniej wielokrotnie krytykował on zachodnioeuropejskich sojuszników za ograniczone wydatki na obronność. Groził także konsekwencjami w postaci przeniesienia z Niemiec do Polski baz amerykańskich. Działanie takie mogłoby jednak negatywnie wpłynąć na spójność NATO, a co za tym idzie, skuteczność jego odstraszania $^{87}$. Nie oznacza to, że proces ten nie jest uzasadniony. Nie powinien być jednak realizowany $w$ atmosferze sporu wewnątrz NATO. Winien mieć charakter ewolucyjny, tym bardziej że obecnie niemieckie lotniska, porty oraz szlaki kolejowe i drogowe są kluczowe w planach obronnych USA w sytuacji agresji Rosji na Europę ${ }^{88}$.

Rozmowy między Polską i USA na temat stałej bazy wojskowej pogłębiły napięcia w stosunkach rosyjsko-amerykańskich i rosyjsko-polskich. Strony intensyfikowały ćwiczenia i manewry wojskowe, przenosiły na pogranicze dodatkowe uzbrojenie i sprzęt wojskowy oraz wzajemnie zarzucały sobie pogwałcenie umów rozbrojeniowych ${ }^{89}$. Stany Zjednoczone realizują te działania we współpracy z sojusznikami z NATO, a Rosja zacieśnia kooperację wojskową z Białorusią. Chce ona m.in. zbudować na terytorium Białorusi, przy granicy z Polską, wojskową bazę powietrzną. Jak dotąd nie spotkało się to z przychylnością Mińska, obawiającego się ograniczenia własnej suwerenności. Prezydent Alaksandr Łukaszenka nie wyklucza jednak takiej decyzji, jeśli dalej zwiększana będzie obecność wojsk USA w Polsce ${ }^{90}$.

Prezydent Trump unika jednoznacznych deklaracji w sprawie stałej obecności wojsk amerykańskich w Polsce. Postawa ta wynika głównie z obaw przed dalszym pogorszeniem stosunków z Rosją, na których poprawie mu zależy ${ }^{91}$. Zapowiedź wysłania do Polski dodatkowych amerykańskich żołnierzy w Moskwie została bardzo negatywnie odebrana. Zastępca ministra spraw zagranicznych Sergei Ryabkov stwierdził, że prawdopodobnie odzwierciedla ona "agresywne” intencje. Z kolei przewodniczący Komisji ds. Obrony Dumy Państwowej Władimir Szamanow przestrzegł przed możliwością przenoszenia ładunków nuklearnych przez amerykańskie drony, które winny trafić do Polski. W odpowiedzi ambasador USA w Warszawie Georgette Mosbacher powiedziała, że działania te mają charakter czysto defensywny, w celu wsparcia zdolności sojusznika do obrony własnych granic ${ }^{92}$.

87 Q. Lopinot, 'Fort Trump?' - Is There Added Value to a Permanent U.S. Military Base in Poland?, 19.11.2018, https://www.csis.org/analysis/fort-trump\%E2\%80\%94-there-added-value-permanentus-military-base-poland (dostęp: 10.07.2019).

88 D.S. Cloud, op. cit.

${ }^{89}$ Stratfor Worldview, op. cit.

90 Łukaszenka: Na Białorusi nie będzie nowej rosyjskiej bazy wojskowej, 14.12.2018, https://pl.sputniknews.com/swiat/201812149396947-Sputnik-Lukaszenka-rosyjska-baza-wojskowa/ (dostęp: 18.07.2019).

${ }^{91}$ D.S. Cloud, op. cit.

92 Reuters, Deploying U.S. Troops in Poland Fully Defensive, Ambassador Says in Retort to Russia, „The Moscow Times” (17 VI 2019), https://www.themoscowtimes.com/2019/06/17/deploying-ustroops-in-poland-fully-defensive-ambassador-says-in-retort-to-russia-a66032 (dostęp: 18.07.2019). 
Według ministra Błaszczaka stała obecność wojsk amerykańskich w Polsce ma zwiększyć skalę odstraszania rosyjskiej ingerencji, jak również stanowić strategiczne zakotwiczenie USA $\mathrm{w}$ europejskie środowisko bezpieczeństwa i pogłębić dwustronne więzi w obszarze obronności między Polską a USA ${ }^{93}$. Minister Błaszczak dostrzega także impuls rozwojowy dla polskiej gospodarki, związany z budową amerykańskiej bazy wojskowej. Szczególnie ma to być widoczne na poziomie lokalnym, w związku z włączeniem przedsiębiorstw w zabezpieczenie infrastrukturalne i logistyczne bazy i amerykańskich żołnierzy ${ }^{94}$. Potencjalnie wzrosnąć mogłaby również ranga Polski na arenie międzynarodowej. Stała baza w Polsce byłaby także ważnym czynnikiem wyrównującym poziom bezpieczeństwa państw wschodniej, zachodniej i południowej flanki NATO ${ }^{95}$. Wśród kontrargumentów należy przede wszystkim wskazać odpowiedź ze strony Rosji, ryzyko uprzedmiotowienia polskiej polityki zagranicznej i bezpieczeństwa względem Waszyngtonu oraz potencjalny wzrost zagrożenia ze strony wrogich USA organizacji terrorystycznych.

Według Centrum Badania Opinii Społecznej (CBOS) z marca 2017 r. 65\% badanych uważało, że w Polsce powinny stacjonować wojska innych państw NATO, z czego 23\% zdecydowanie popierało tę ideę, a $42 \%$ umiarkowanie. Przeciwnych tej koncepcji było $24 \%$ respondentów, z czego $18 \%$ umiarkowanie, a $6 \%$ zdecydowanie. $11 \%$ badanych nie miało zdania w tej kwestii ${ }^{96}$. Dwa lata później, tj. w marcu 2019 r. wyniki badań CBOS były prawie identyczne. Także $65 \%$ ankietowanych opowiadało się za stacjonowaniem w kraju wojsk NATO, z czego $22 \%$ zdecydowanie, a $43 \%$ umiarkowanie. Przeciwnych stacjonowaniu było $25 \%$ badanych, $\mathrm{w}$ tym $18 \%$ umiarkowanie, a $5 \%$ zdecydowanie. Wyrobionego zdania nie miało $10 \%$ pytanych osób ${ }^{97}$. Wysokie poparcie społeczeństwa dla stacjonowania w Polsce wojsk sojuszniczych jest dla władz krajowych ważnym, dodatkowym argumentem.

Wśród elit politycznych w Stanach Zjednoczonych jak na razie nie ma poparcia dla idei budowy w Polsce „Fortu Trump” i stałego stacjonowania w niej amerykańskiej dywizji pancernej. Wynika to m.in. z trzech istotnych procesów, które zachodzą w polityce amerykańskiej. Po pierwsze, w konsekwencji problemów budżetowych istnieje duża presja na redukcję wydatków zbrojeniowych. Po drugie, następuje reorientacja strategiczna Stanów Zjednoczonych na rejon Azji i Pacyfiku.

${ }^{93}$ Minister Blaszczak in The Washington Times: American base in Poland will strengthen regional security, 17.09.2018, https://www.gov.pl/web/national-defence/minister-blaszczak-in-the-washington-times-american-base-in-poland-will-strengthen-regional-security (dostęp: 18.07.2019).

94 Pc, PAP, Co da stała baza amerykańska w Polsce? Szef MON: „To byłby bardzo wyraźny sygnał, że ten rejon świata jest bezpieczny". WYWIAD, 28.09.2018, https://wpolityce.pl/polityka/414276szef-mon-stala-baza-amerykanska-to-szansa-na-zmiane-epokowa (dostęp: 18.07.2019).

95 J. Graf, J. Palowski, op. cit.

96 CBOS, Stosunek do NATO i obecności wojsk sojuszniczych $w$ naszym kraju. Komunikat z badań $n$ r 26/2017, Warszawa 2017, s. 7, https://www.cbos.pl/SPISKOM.POL/2017/K_026_17.PDF (dostęp: 12.07.2019).

97 CBOS, 20 lat członkostwa Polski w NATO. Komunikat $z$ badań $n r$ 31/2019, Warszawa 2019, s. 15, https://cbos.pl/SPISKOM.POL/2019/K_031_19.PDF (dostęp: 12.07.2019). 
Po trzecie, wzrasta poparcie dla idei neoizolacjonizmu w polityce zagranicznej USA $^{98}$. Ponadto można wskazać kilka bardziej szczegółowych argumentów. Po pierwsze, armia USA nie ma wolnej jednostki bojowej tego rodzaju, którą mogłaby przegrupować do Polski. Po drugie, środki zaproponowane przez Polskę, mimo że znaczne, to z pewnością nie wystarczyłyby na realizację długoterminowych inwestycji i utrzymania sił. Po trzecie, polska propozycja nie była spójna $\mathrm{z}$ amerykańskimi planami dotyczącymi rozmieszczenia wojsk zagranicą. Po czwarte, mogłoby to negatywnie wpłynąć na postawę państw Europy Zachodniej, ponieważ większość z nich nie jest chętna do podejmowania bardziej zdecydowanych działań wobec Rosji ${ }^{99}$. Środowisko, dzięki któremu Trump doszedł do władzy, zasadniczo opowiada się za skupieniem na sprawach wewnętrznych, kosztem angażowania się USA na świecie. Neokonserwatyści generalnie sprzeciwiają się ustępstwom wobec Rosji. Obawiają się jednak, że budowa bazy u jej granic może legitymizować wzrost jej aktywności wojskowej i tym samym pogłębić destabilizację. Zdecydowanie ideę tę krytykuje lewica. Przedstawiciele Partii Demokratycznej wskazują na koszty przedsięwzięcia oraz pogorszenie stosunków z Rosją i ewentualnie także z Niemcami ${ }^{100}$. Były sekretarz obrony USA James Mattis stwierdził, że docenia ofertę Polaków, jednak nie uważa, aby Amerykanie jej potrzebowali ${ }^{101}$.

Powyższe nie oznacza, że wśród amerykańskich polityków nie ma osób, które popierają zwiększenie poziomu obecności wojskowej w Polsce. Z perspektywy USA główny argument przemawiający za stałym stacjonowaniem wojsk amerykańskich w Polsce stanowi zwiększenie poziomu odstraszania na wschodniej flance NATO. Ponadto rotacyjność sił jest kosztowna, nieefektywna i obciążająca dla sił zbrojnych. Dziewięciomiesięczne rotacje brygad powodują również spadek morale żołnierzy, wywołany długotrwałą rozłąką z rodziną. Ponieważ kwestie te dotyczą bezpośrednio wojskowych, wśród nich jest znacznie większy poziom poparcia dla stałego stacjonowania w Polsce, niż wśród polityków. Przykładowo gen. Scaparrotti apelował o rozmieszczenie w Europie brygady artylerii, brygady lotnictwa bojowego, a na dalszym etapie także brygady pancernej. Część tych sił miałaby trafić do Polski ${ }^{102}$. Natomiast Alexander Lanoszka i Michael A. Hunzeker ze Strategic Studies Institute U.S. Army War College uważają stałe stacjonowanie kompanii w poszczególnych państwach wschodniej flanki za nieefektywne operacyjnie. Nie są one bowiem zdolne do prowadzenia samodzielnych operacji ze względu na brak odpowiedniego zaplecza logistycznego. Za zasadne uznają oni

98 A.A. Michta, Konsekwencje dla NATO wynikajace $z$ sytuacji wewnętrznej $i$ zmiany globalnych priorytetów polityki obronnej USA, w: Polityczno-wojskowe implikacje..., s. 56.

99 P.B. Doran, R. Wojcik, Unfinished Business. Why and How the U.S. Should Establish a Permanent Military Presence on NATO's Eastern Flank, 11.2018, s. 3, https://docs.wixstatic.com/ugd/ 644196_4a56ab7a60a642daa6c5a609da158b7e.pdf (dostęp: 10.07.2019).

100 R. Korzycki, op. cit.

101 Q. Lopinot, op. cit.

102 J. Graf, J. Palowski, op. cit. 
zmianę formuły stacjonowania $\mathrm{z}$ rotacyjnego na stałe większej jednostki wyposażonej w takie zdolności. W związku z tym proponują stałe stacjonowanie brygady pancernej w Polsce ${ }^{103}$.

\section{Zakończenie}

Po zakończeniu zimnej wojny Polska próbowała być postrzegana w Stanach Zjednoczonych jako modelowy partner i sojusznik. Wynikało to $\mathrm{z}$ traktowania USA jako gwaranta bezpieczeństwa Europy i Polski. Warszawa stała się jednym z najbardziej zdecydowanych i konsekwentnych stronników Waszyngtonu, jak i rzecznikiem solidarności transatlantyckiej ${ }^{104}$. W drugiej dekadzie XXI w. Siły Zbrojne Stanów Zjednoczonych zaczęły być obecne na terytorium Polski na zasadzie stałej rotacji. Przede wszystkim wiąże się to ze wzrostem zagrożenia na wschodniej flance NATO. Na potrzeby stacjonowania amerykańskich żołnierzy rozbudowywane i modernizowane są bazy w Polsce, głównie w Powidzu, Łasku, Żaganiu i Drawsku Pomorskim oraz powstaje nowa baza w Redzikowie.

Obecnie władze polskie zabiegają o stałe stacjonowanie wojsk amerykańskich na terytorium Rzeczypospolitej. Działania te mają charakter strategiczny i długofalowy. Ich konsekwencje dotyczyć będą nie tylko okresu funkcjonowania obecnego rządu, ale mają sięgać kolejnych dekad. $Z$ tego względu bardzo ważne jest, że koncepcja ta cieszy się poparciem głównych ugrupowań politycznych, jak również społeczeństwa polskiego.

Propozycja Warszawy, obejmująca stałe stacjonowanie w Polsce amerykańskiej dywizji pancernej, jest ambitna, jednak w obecnej sytuacji międzynarodowej mało realna do zaakceptowania przez stronę amerykańską. Możliwe jednak, że wyjście $\mathrm{z}$ tak daleko idącą ofertą stanowiło celowy zabieg negocjacyjny, ukierunkowany na przynajmniej częściowe jej zaakceptowanie przez USA. Przedstawiona przez Waszyngton kontrpropozycja daleko odbiega od polskiego projektu „Fort Trump". Niewykluczone jednak, że w przyszłości Stany Zjednoczone będą stopniowo zwiększać swoje zaangażowanie wojskowe w Polsce, zbliżając się do oczekiwań Warszawy. Zależeć będzie to przede wszystkim od ewolucji europejskiego środowiska bezpieczeństwa, jak i sytuacji wewnętrznej w USA. Obecnie zastanowienie budzi strona kosztowa przedsięwzięcia. Kwota 1,5-2 mld USD zaproponowana została przez Polskę przy bardzo ambitnym projekcie wyjściowym. Pytanie więc, czy wraz z jego poważną modyfikacją obniżony zostanie także poziom partycypacji kosztowej w przedsięwzięciu? Czy może ma to być „zadatek” zachęcający USA do perspektywicznego zwiększania obecności wojskowej w Polsce?

103 A. Lanoszka, M.A. Hunzeker, Conventional Deterrence and Landpower in Northeastern Europe, 03.2019, s. XV-XVI, 107, https://ssi.armywarcollege.edu/pubs/display.cfm?pubID=1404 (dostęp: 10.07.2019).

104 N. Bouchet, op. cit., s. 88, 168. 
Należy podkreślić, że stacjonowanie wojsk amerykańskich na terytorium Rzeczypospolitej i ich uczestnictwo w szeregu przedsięwzięć militarnych jest wiarygodnym czynnikiem odstraszania i obrony. Stanowi ono faktyczne potwierdzenie formalnych zobowiązań i gwarancji w obszarze bezpieczeństwa. Polska jako lojalny sprzymierzeniec, ponoszący ciężary i zobowiązania sojusznicze oraz sukcesywnie modernizujący własne siły zbrojne, szczególnie zasługuje na wsparcie ze strony Stanów Zjednoczonych ${ }^{105}$. Trzeba jednak pamiętać, że $w$ wielu państwach USA spotykają się z niechęcią wobec ich "monopolu na potęgę" i nie zawsze odpowiednie korzystanie $\mathrm{z}$ niego. Tak blisko wiążąc własne interesy bezpieczeństwa i obrony z USA, Polska musi także liczyć się z krytyką za działania supermocarstwa i współuczestnictwo $\mathrm{w}$ organizowanych przez nie przedsięwzięciach. Co niepokojące, krytyka tych działań pojawia się także w ramach Sojuszu Północnoatlantyckiego. Jednocześnie trudno sobie wyobrazić operacje militarne NATO bez przywództwa, a przynajmniej zgody i wsparcia ze strony USA ${ }^{106}$. Dla Polski najważniejszym tego potwierdzeniem są działania na rzecz zabezpieczenia wschodniej flanki NATO przed wzrastającym zagrożeniem ze strony Rosji.

\section{The Polish Authorities' Efforts to Locate the United States Armed Forces Permanent Military Base on the Territory of the Republic of Poland}

\section{Abstract}

The article is devoted to the attempts of the Polish authorities to locate a permanent military base of the US Armed Forces in the territory of the Republic of Poland. The introduction outlines the main areas of political and military cooperation between Poland and the US. The next parts of the text present the location of US military installations in Poland, negotiations regarding the site of a permanent American military base in its territory and the conditions under which that would be supposed to happen. The primary purpose of the article is to analyse and evaluate the legitimacy and effectiveness of the Polish authorities' efforts to locate a permanent US military base in Poland. The main research problem is the question of whether the actions taken by the Polish authorities regarding the location of a permanent American military base in its territory are justified and effective? The basic thesis is that the concept of 'Fort Trump' presented by Poland is extremely ambitious and impossible to implement in the current situation. However, the United States is ready to gradually increase its military involvement in Poland, which may, in the future, bring them closer to the expectations of the Polish party. However, this will depend primarily on the direction of the evolution of European security, as well as the internal situation in the United States. The article uses the method of analysing text sources and elements of the decision method.

105 Q. Lopinot, op. cit.

106 D. Stokwiszewski, Ewolucja polityki zagranicznej i obronnej Rzeczypospolitej Polskiej w ramach euroatlantyckiego systemu bezpieczeństwa w latach 1999-2013, Warszawa 2014, s. 259. 


\section{Усилия польских властей, направленные на размещение на территории Польской Республики постоянной военной базы Вооруженных сил США}

\section{Аннотация}

Предметом статьи являются действия польских властей по размещению на территории Польской Республики постоянной военной базы ВВС США. Во вступлении были обозначены главные области политико-военного сотрудничества Польши и США. Очередные части текста касаются размещения в Польше военных установок США, переговоров о размещении на ее территории постоянной американской военной базы, а также условия данного начинания. Главной целью данной статьи является анализ и оценка обоснований, а также успешности хлопот польских властей о размещении постоянной военной базы США в Польше. Главная исследовательская задача состоит из следующего вопроса: являются ли действия, предпринимаемые польскими властями, по размещению на польской территории постоянной американской военной базы обоснованными и эффективными? Основным тезисом является утверждение о том, что предложенная Польшей концепция «Форта Трамп» - необыкновенно амбициозная и в нынешней ситуации ее нельзя реализовать. Однако США готовы постепенно увеличивать военное присутствие в Польше, так что в будущем оно может больше соответствовать ожиданиям польской стороны. Однако все будет зависеть, прежде всего, от направления эволюции европейской безопасности как и внутренней обстановки в США. В статье автор воспользовался методом анализа текстовых источников, а также элементами метода принятия решений.

\section{Bibliografia}

Apeldoorn van B., Graaff de N., American Grand Strategy and Corporate Elite Networks. The Open Door since the End of the Cold War, London-New York 2016.

Aslam W., The United States and Great Power Responsibility in International Society. Drones, rendition and invasion, London-New York 2013.

Balcer A., Wóycicki K., Polska na globalnej szachownicy, Warszawa 2014.

Bandeira L.A.M., The Second Cold War Geopolitics and the Strategic Dimensions of the USA, New York 2017.

Bouchet N., Democracy Promotion as US Foreign Policy Bill Clinton and Democratic Enlargement, London-New York 2015.

Cameron F., US Foreign Policy after the Cold War. Global Hegemon or Reluctant Sheriff? Second edition, London-New York 2005.

David M., US-Russia relations in Obama's second term: a damage limitation exercise, $\mathrm{w}$ : The Obama Doctrine. A Legacy of Continuity in US Foreign Policy?, ed. M. Bentley, J. Holland, London-New York 2017, s. 164-179.

Dumbrell J., Clinton's Foreign Policy Between the Bushes, 1992-2000, London-New York 2009.

Dunn D.H., Zala B., Transatlantic relations and US foreign policy, w: Obama and the World New Directions in US Foreign Policy. Second edition, ed. I. Parmar, L.B. Miller, M. Ledwidge, London-New York 2014, s. 197-219.

Gardner H., American Global Strategy and the „War on Terrorism”, London-New York 2016. 
Grodzki R., Polska polityka zagraniczna w XX i XXI wieku. Główne kierunki - Fakty - Ludzie - Wydarzenia, Zakrzewo 2009.

Haglund D.G., The US-Canada relationship: How 'special' is America's oldest unbroken alliance?, w: America's 'Special Relationships'. Foreign and Domestic Aspects of the Politics of Alliance, ed. J. Dumbrell, A.R. Schäfer, London-New York 2009, s. 60-75.

Hallams E., The United States and NATO since 9/11. The transatlantic alliance renewed, London-New York 2010.

Hansen B., Toft P., Wivel A., Security Strategies and American World Order Lost Power, London-New York 2009.

Holsti O.R., Making American Foreign Policy, London-New York 2006.

Kiwerska J., Kwestie bezpieczeństwa w stosunkach polsko-amerykańskich. Trendy i perspektywy, w: Bezpieczeństwo Polski. Współczesne wyzwania, red. S. Wojciechowski, A. Potyrała, Warszawa 2014, s. 60-80.

Koziej S., Fryc M., NATO po zakończeniu operacji w Afganistanie, w: Polityczno-wojskowe implikacje członkostwa Polski w NATO z perspektywy 15-lecia obecności w strukturach Sojuszu, red. T. Kośmider, Warszawa 2014, s. 45-54.

Lee L.R., US Hegemony and International Legitimacy. Norms, power and followership in the wars on Iraq, London-New York 2010.

Lieber R.J., The United States and Europe: Explaining the Transatlantic Bonds, w: American Foreign Policy in a Globalized World, ed. D.P. Forsythe, P.C. McMahon, A. Wedeman, London-New York 2006, s. 261-286.

Michta A.A., Konsekwencje dla NATO wynikajace z sytuacji wewnętrznej i zmiany globalnych priorytetów polityki obronnej USA, w: Polityczno-wojskowe implikacje członkostwa Polski w NATO z perspektywy 15-lecia obecności w strukturach Sojuszu, red. T. Kośmider, Warszawa 2014, s. 55-65.

Moens A., The Foreign Policy of George W. Bush. Values, Strategy, and Loyalty, London-New York 2016.

Orzelska A., Polityka zagraniczna Polski wobec wybranych kwestii spornych $w$ stosunkach transatlantyckich (1989-2004), Warszawa 2011.

Renshon S.A., National Security in the Obama Administration. Reassessing the Bush Doctrine, London-New York 2010.

Rusak R., Wspótpraca wojskowo-techniczna Polski z USA, w: Polska w międzynarodowej współpracy wojskowej, red. T. Kubaczyk, S. Piotrowski, M. Żyła, Warszawa 2016, s. 307-324.

Shor F., Dying Empire. U.S. Imperialism and Global Resistance, London-New York 2010.

Steff R., Strategic Thinking, Deterrence and the US Ballistic Missile Defense Project. From Truman to Obama, London-New York 2016.

Stokwiszewski D., Ewolucja polityki zagranicznej i obronnej Rzeczypospolitej Polskiej w ramach euroatlantyckiego systemu bezpieczeństwa w latach 1999-2013, Warszawa 2014.

Sylvan D., Majeski S., U.S. Foreign Policy in Perspective. Clients, Enemies and Empire, London-New York 2009.

Symonides J., Polityka zagraniczna Polski a ład międzynarodowy, w: Polityka zagraniczna Polski po wstapieniu do NATO $i$ do Unii Europejskiej. Problemy tożsamości i adaptacji, red. S. Bieleń, Warszawa 2010, s. 71-105.

Terriff T., Grace, murder, or suicide? The passing of American primacy, w: Debating a Post-American World. What Lies Ahead?, ed. S. Clark, S. Hoque, London-New York 2012, s. $47-53$.

Toje A., America, the EU and Strategic Culture. Renegotiating the Transatlantic Bargains, London-New York 2008.

Walton C.D., Grand Strategy and the Presidency. Foreign Policy, War and the American Role in the World, London-New York 2012. 
Warren A., The Obama Administration's Nuclear Weapon Strategy. The Promises of Prague, London-New York 2014.

Zięba R., Główne kierunki polityki zagranicznej Polski po zimnej wojnie, Warszawa 2010.

Zięba R., Polityka zagraniczna Polski w strefie euroatlantyckiej, Warszawa 2013.

Łukasz Jureńczyk, dr hab., prof. UKW; pracuje na Wydziale Nauk o Polityce i Administracji Uniwersytetu Kazimierza Wielkiego w Bydgoszczy, pełniąc funkcję kierownika Katedry Polityki Bezpieczeństwa. Specjalizuje się w międzynarodowych stosunkach politycznych i polityce bezpieczeństwa (lukaszjurenczyk@ukw.edu.pl).

Eukasz Jureńczyk, dr. hab., associate prof. at the Kazimierz Wielki University; employee of the Faculty of Political Sciences and Public Administration of KWU in Bydgoszcz, Head of the Department of Security Policy. He specialises in international political relations and security policy (lukaszjurenczyk@ukw.edu.pl). 